general hospital 1972-1980: clinical and laboratory features, classification and prognosis of 80 cases. $Q \mathcal{F}$ Med 1982;51:292-311.

${ }^{3}$ Cohen RD, Conn DL, Ilstrup DM. Clinical features, prognosis and response to treatment in polyarteritis. Mayo Clin Proc 1980;55:146-55.

+ Hind CRK, Paraskewakou H, Lockwood CM, et al. Prognosis after immunosuppression of patients with crescentic nephritis requiring dialysis. Lancet $1983 ; \mathrm{i}: 263-5$.

${ }^{5}$ Pepys MB. Acute phase phenomena. In: Cohen AS, ed. The science and practice of clinical medicine: rheumatology and immunology. New York: Grune and Stratton, 1979:85-9.

6 International Committee for Standardisation in Haematology. Reference method for the erythrocyte sedimentation rate (ESR) test on human blood. Br $\mathcal{F}$ Haematol 1973;23:671-3.

${ }^{7}$ Pepys MB. C-reactive protein fifty years on. Lancet 1981 ; :653-7.

${ }^{8}$ Camilleri M, Pusey CD, Chadwick VS, Rees AJ. Gastrointestinal manifestations of systemic vasculitis. $Q \mathcal{F}$ Med $1983 ; 52: 141-9$.

9 Ewan PW, Jones HA, Rhodes CG, Hughes JMB. Detection of pulmonary hemorrhage with carbon monoxide uptake. N Engl f Med 1976;295: 1391-6.
11) Fagan EA, Dyck RF, Maton PN, et al. Serum levels of C-reactive protein in Crohn's disease and ulcerative colitis. Eur 7 Clin Invest $1982 ; 12: 351-9$

${ }^{11}$ Shine B, de Beer FC, Pepys MB. Solid phase radioimmunoassays for C-reactive protein. Clin Chim Acta 1981;117:13-23.

12 de Beer FC, Hind CRK, Fox KM, et al. Measurement of serum C-reactive protein concentration in myocardial ischaemia and infarction. $\mathrm{Br} \mathrm{Heart}$ f $1982 ; 47: 239-43$.

13 Mallya RK, Vergani D, Tee DEH, et al. Correlation in rheumatoid arthritis of concentrations of plasma $\mathrm{C} 3 \mathrm{~d}$, serum rheumatoid factor, immune complexes and C-reactive protein with each other and with clinical features of disease activity. Clin Exp Immunol 1982;48:747-53.

14 Hind CRK, Winearls CG, Lockwood CM, Rees AJ, Pepys MB. Objective monitoring of activity in Wegener's granulomatosis by measurement of serum C-reactive protein concentration. Clin Nephrol (in press).

15 de Beer FC, Pepys MB. Solid-phase immunoradiometric assay for Creactive protein using magnetisable cellulose particles. $\mathcal{f}$ Immunol Methods 1982;50:299-308.

(Accepted 31 fanuary 1984)

\title{
Vitamin A treatment for night blindness in primary biliary cirrhosis
}

\author{
R P WALT, C M KEMP, L LYNESS, A C BIRD, S SHERLOCK
}

\begin{abstract}
Three patients with late stage primary biliary cirrhosis were found to have appreciable night blindness. Serum vitamin $A$ concentrations were low in all three patients despite regular intramuscular supplementation in two. All patients responded dramatically to high dose oral supplementation, with full recovery of adaptation to dark and visual fields.

Oral rather than intramuscular vitamin A supplementation seems appropriate in the prevention of ocular complications of vitamin A deficiency in biliary cirrhosis.
\end{abstract}

\section{Introduction}

Vitamins that are soluble in fat are poorly absorbed in cholestatic liver disease, but routine measurements of vitamin $A$ in 20 patients with primary biliary cirrhosis showed that three had pathologically low concentrations despite receiving intramuscular supplementation with vitamin $\mathrm{A}$; two of these three patients had symptomatic night blindness. We report on these three patients.

Academic Department of Medicine, Royal Free Hospital School of Medicine, London NW3 2PF

R P WALT, MRCP, medical registrar

S SHERLOCK, DBE, MD, FRCP, professor

Departments of Visual Science and Clinical Ophthalmology, Institute of Ophthalmology, London WC1H 9OS, and Moorfields Eye Hospital, London EC1 2PD

C M KEMP, PHD, senior lecturer

L LYNESS, FRCS, senior registrar

A C BIRD, MD, FRCS, professor

Correspondence to: Dr R P Walt, Department of Therapeutics, University Hospital, Nottingham NG7 2UH.

\section{Patients, methods, and results}

We measured serum vitamin A concentrations by high pressure liquid chromatography ${ }^{1}$ (normal range $0 \cdot 7-3 \cdot 1 \mu \mathrm{mol} / 1(20-90 \mu \mathrm{g} /$ $100 \mathrm{ml}$ ) ) and gave vitamin A supplements intramuscularly (Ro-A-Vit, Roche) or by mouth (vitamin A capsules, Macarthys). We used a Goldmann perimeter to measure photopic function and an automated perimeter adaptometer to record the course and extent of cone and rod adaptation after an intense xenon flash. ${ }^{2}$

The table gives details of the patients when they presented initially with primary biliary cirrhosis.

Case 1-This woman presented in 1982 after noticing difficulty in driving at night. Her liver disease had worsened considerably (serum bilirubin concentration $660 \mu \mathrm{mol} / 1(38.8 \mathrm{mg} / 100 \mathrm{ml}))$. Her visual field was constricted. Adaptation to the dark was absent (figure, curve $\mathrm{A}$ ), and cone thresholds were raised by more than one log unit.

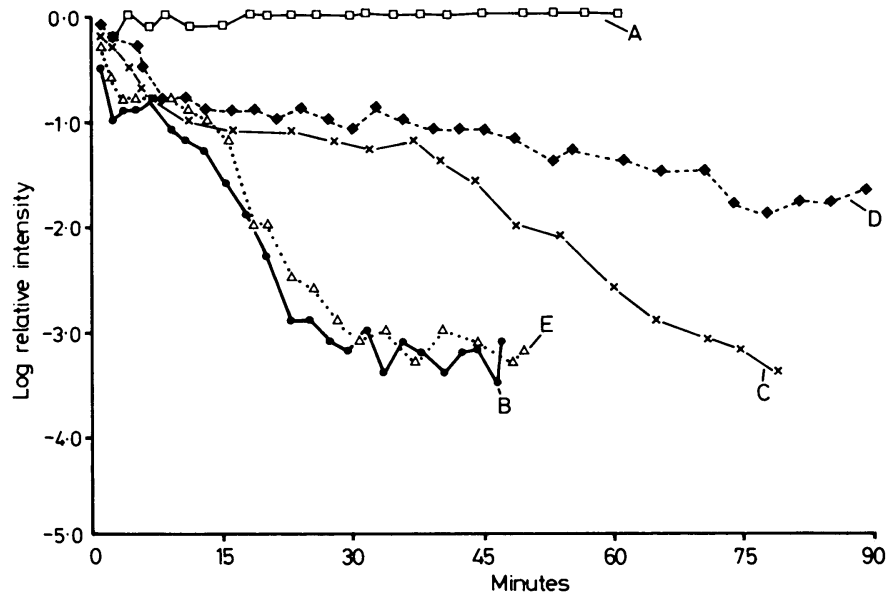

Dark adaptation curves (case 1) measured with flashing yellow-green test light $(\lambda=530 \mathrm{~nm})$ subtending a visual angle of $1^{\circ}$. Data points describe the log relative intensity needed for the test light to be just seen. The maximum intensity of the flash was designated as $0 \mathrm{log}$ units; stimuli that were not seen at all are shown as $+0 \cdot 1$. (Curve $A$, day 0 ; oral treatment started on day 4 ; curve $B$, day 11 ; treatment stopped on day 40 ; curve $C$, day 55 ; curve $D$, day 60 ; treatment restarted on day 61 ; curve $E$, day 74 .) 
Details of liver disease in patients at time of initial presentation

\begin{tabular}{|c|c|c|c|}
\hline & Case 1 & Case 2 & Case 3 \\
\hline $\begin{array}{l}\text { Age (years) } \\
\text { Year of presentation } \\
\text { Alkaline phosphatase activity }(\text { IU } / 1)(\text { normal }<130) \\
\text { Bilirubin }(\mu \text { mol/1) (normal }<17) \\
\text { Mitochondrial antibody } \\
\text { Liver biopsy } \\
\text { Treatment }\end{array}$ & 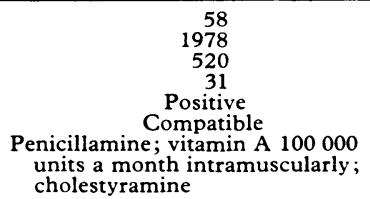 & $\begin{array}{c}54 \\
1976 \\
585 \\
69 \\
\text { Positive } \\
\text { Compatible } \\
\text { Pencillamine; vitamin A } 100000 \\
\text { units a month intramuscularly } \\
\text { (until May 1982); cholestyramine }\end{array}$ & $\begin{array}{c}61 \\
1976 \\
690 \\
36 \\
\text { Negative } \\
\text { Compatible } \\
\text { Penicillamine; vitamin A } 100000 \\
\text { units a month intramuscularly; } \\
\text { zinc sulphate; cholestyramine }\end{array}$ \\
\hline
\end{tabular}

Conversion: SI to traditional units-Bilirubin: $1 \mu \mathrm{mol} / 1=58.5 \mu \mathrm{g} / 100 \mathrm{ml}$.

Her serum vitamin A concentration was $<0 \cdot 17 \mu \mathrm{mol} / 1(5 \mu \mathrm{g} / 100 \mathrm{ml})$ As dark adaptation and vitamin $A$ concentration had not improved four days after an intramuscular injection of $100000 \mathrm{U}$ vitamin $\mathrm{A}$, oral vitamin A $50000 \mathrm{U}$ daily was started. On day 7 the Goldmann field was normal and her serum vitamin A concentration was $0.7 \mu \mathrm{mol} / 1$ $(19 \mu \mathrm{g} / 100 \mathrm{ml})$. Adaptation to dark showed normal cone thresholds, but rod function remained undetectable. On day 11 dark adaptation was within the normal range (figure, curve $B$ ) and the serum vitamin $A$ concentration was $1 \mu \mathrm{mol} / 1(28 \mu \mathrm{g} / 100 \mathrm{ml})$. The dose of vitamin A was halved and continued for one month. On day 40 all tests gave normal results. Vitamin A supplements were then withdrawn, and by day 55 , although she was asymptomatic, dark adaptation was slowed (figure, curve C) and serum vitamin A concentration was $0.5 \mu \mathrm{mol} / 1(14 \mu \mathrm{g} / 100 \mathrm{ml})$. On day 60 dark adaptation was worse (figure, curve D) and serum vitamin A concentration $0.3 \mu \mathrm{mol} / \mathrm{l}$ $(8 \mu \mathrm{g} / 100 \mathrm{ml})$, although she remained asymptomatic. Vitamin A was restarted at $25000 \mathrm{U}$ daily, and by day 74 there was full recovery (figure, curve E), with serum vitamin A concentration $1.3 \mu \mathrm{mol} / 1$ $(37 \mu \mathrm{g} / 100 \mathrm{ml})$.

Case 2-This woman presented in 1982 after noticing difficulty in seeing at night. Her liver disease had progressed (serum bilirubin concentration $259 \mu \mathrm{mol} / 1(15 \cdot 2 \mathrm{mg} / 100 \mathrm{ml}))$. Her serum vitamin A concentration was $<0.17 \mu \mathrm{mol} / 1(5 \mu \mathrm{g} / 100 \mathrm{ml})$, and rod adaptation was grossly slowed (increase of $1.5 \mathrm{log}$ units after 60 minutes). Oral vitamin A $50000 \mathrm{U}$ daily was started. On day 3 adaptation to dark was normal and her serum vitamin A concentration $1.0 \mu \mathrm{mol} / 1$ $(28 \mu \mathrm{g} / 100 \mathrm{ml})$. The dose of vitamin A was halved, and visual function remained normal. Vitamin A concentrations subsequently remained over $1.05 \mu \mathrm{mol} / 1(30 \mu \mathrm{g} / 100 \mathrm{ml})$.

Case 3-This woman presented in 1982 with a bilirubin concentration of $375 \mu \mathrm{mol} / 1(22 \mathrm{mg} / 100 \mathrm{ml})$. Three weeks after an injection of $100000 \mathrm{U}$ vitamin A intramuscularly adaptation to dark was very slow (110 minutes). One week after a further injection of $100000 \mathrm{U}$ vitamin $\mathrm{A}$ adaptation to dark was worse and the serum vitamin A concentration was $0.2 \mu \mathrm{mol} / 1(6 \mu \mathrm{g} / 100 \mathrm{ml}))$; a week later there was no rod function (vitamin A concentration $<0.17 \mu \mathrm{mol} / \mathrm{l}(5 \mu \mathrm{g} /$ $100 \mathrm{ml}))$. Oral supplements $(25000 \mathrm{U}$ daily) were started. Seven days later (day 22) she was free of symptoms, although full adaptation to dark required 55 minutes (longer than expected in normal subjects). Her vitamin A concentration was $1.0 \mu \mathrm{mol} / 1(29 \mu \mathrm{g} / 100 \mathrm{ml})$. Further investigation could not be performed because of clinical deterioration.

\section{Discussion}

Vitamin A deficiency and slight night blindness commonly occur in primary biliary cirrhosis, ${ }^{3}$ but severe night blindness seems to occur only at the later stages of the disease. This deterioration may be due either to aggravation of a metabolic defect $^{4}$ or to poor synthesis and release of retinol binding protein. ${ }^{5}$ The failure of intramuscular vitamin A to restore serum concentrations and visual function is surprising and unexplained, but oral vitamin A was effective.

We suggest that patients with advanced primary biliary cirrhosis should be given oral vitamin A. As absorption may be poor treatment should be regulated by monitoring of visual function and serum vitamin A concentrations to limit the risk of toxicity. An adequate initial dose is $25000 \mathrm{U}$ daily, although lower doses may be effective. Further investigations are needed to identify the prevalence of this serious and preventable complication of primary biliary cirrhosis and to establish the therapeutic range of vitamin $\mathrm{A}$.
We thank the Royal National Institute for the Blind and the Wellcome Foundation for financial help, and Mrs K Shah for her skilled technical help.

\section{References}

${ }^{1}$ Bieri JG, Tolliver TBS, Catignani GL. Simultaneous determination of $\alpha$-tocopherol and retinol in plasma or red cells by high pressure liquid chromatography. Am $\mathcal{F}$ Clin Nutr 1979;32:2143-9.

2 Ernst W, Faulkner DJ, Hogg CR, Powell DJ, Arden GB, Vaegan. An automated static perimeter/adaptometer using light emitting diodes. Br f Ophthalmol 1983;67:431-42.

${ }^{3}$ Herlong HF, Russell RM, Maddrey WC. Vitamin A and zinc therapy in primary biliary cirrhosis. Hepatology $1981 ; 1: 348-51$.

${ }^{4}$ Hirosawa K, Yamada K. The localisation of the vitamin A in the mouse liver as revealed by electron microscope radioautography. $\mathcal{F}$ Electron Microsc (Tokyo) 1973;22:337-46.

${ }^{5}$ Muto Y, Smith J, Milch P, Goodman DS. Regulation of retinol binding protein metabolism by vitamin A status in the rat. $\mathcal{f}$ Biol Chem 1972 ; 247:2542-50.

(Accepted 4 Fanuary 1984)

ONE HUNDRED YEARS AGO Our Paris correspondent writes: The plague has broken out in the Ottoman territory, in the Bedra district. A sanitary inspection has ascertained that the plague has now attacked Bedra, Dyessan, Mendeli, and Zorbatia; also affecting the Arab tribes, wandering or settled, camped within this area. Bedra is about ten or fifteen hours' journey from Bagdad; but, at the present time, the inundation which is ravaging Mesopotamia renders communication laborious. The overflowing of the Tigris has converted Bagdad into an island, and couriers take eight days to go from Bagdad to Bedra and return. The danger of the plague spreading is centered in the north. Mendeli is already attacked. The road from Hanneguine to Bagdad serves as the high road, and is traversed by all the pilgrims journeying from Persia to Bagdad. The districts of Dizfoul and Chuster lie to the south-east. If the epidemic reach the Lower Tigris, towards Kout-el-mara, it would probably travel along the innumerable canals which cut up this territory, and would devastate Trak-Arabi southwards, as happened in 1875, when more than twenty thousand inhabitants perished. Should the plague travel to the port of Bassorah, the danger that would result is evident; also the necessity for framing protective measures. Egypt now exacts twentyfour hours' surveillance on all importations from this port, and has rigorously prohibited the importation of rags, or of clothes already worn. It is stated that the plague appeared at Bedra two months ago; but it may really date from several months back. There are no precise data, and no one knows. There is one thing certain: the plague is endemic at Trak-Arabi. Since the terrible epidemic of 1830 , it has never been quite stamped out any more than in Kurdistan in Persia. There are yearly epidemics of plague in the Persian Kurdistan. It exists also in the Persian Khorassan, probably in Afghanistan, and certainly in a permanent form southwards of the Anglo-Indian Himalayas. Specialists believe that it exists in Yun-Nan, China. In all the epidemics at Trak-Arabi a diurnal temperature of $40^{\circ}$ Centigrade made it disappear. The International Sanitary Council of Constantinople has taken sanitary measures. Dr. Lubiez, of Bagdad, Dr. Saad, of Hanneguine, and Pardálaki, of Bassorah, are on the spot. They tend the plague-stricken, aided by indigenous civil and military medical men. (British Medical fournal $1884 ; \mathrm{i}: 964$. 